\title{
Ideologies, Alignments, and Underbalancing in the New Middle East Cold War
}

\author{
F. Gregory Gause, III, Texas A\&M University
}

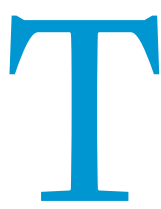

he pattern of alliances and alignments in the Middle East following the Arab uprisings challenges established theories of regional international relations (IR) in intriguing ways (Gause 2014; see also Lynch 2016; Ryan 2012; Salloukh 2013). One notable element of current regional geopolitics is the failure of other local powers to form effective blocking or balancing alliances against Iran, the state that has most clearly improved its regional position as a result of upheavals that go back to the 2003 Iraq War. Even as they fail to form new alliances, however, regional actors are taking steps domestically to increase their military power and cultivating non-state actors to increase their regional influence. This "underbalancing" (Schweller 2004, 2006) in terms of stateto-state alignment is best explained not by sectarianism or balance of power logic but rather by a variant of Walt's (1987) balance-of-threat framework that emphasizes ideology and domestic-regime security issues. Explaining these patterns, therefore, requires grappling with constructivist theories of identity, the drivers of regime insecurity, and the relative importance of state-to-state and transnational policies.

These patterns make for an interesting case not only for thinking through contemporary regional politics but also for testing more general theories about alliances. This effort is a response to Valbjørn's (2017) call in this symposium for scholars of Middle East IR to engage more directly in the broader theoretical field and to use their empirical work on the region to suggest ways that more general IR theories can be amended to explain a wider array of cases.

\section{“UNDERBALANCING" AND THE NEW MIDDLE EAST COLD WAR}

Iran is the undoubted winner in regional-power terms in the past decade of Middle Eastern upheaval. For years, Iraq balanced against Iranian power in ways ranging from political competition to the massively destructive eight-year war in the 1980 os. Today, Iran is the most influential player in Iraqi politics, having close relations with the Baghdad government, sponsoring if not controlling a number of Shi'i militias, maintaining a cooperative relationship with the Kurdish Regional Government, and indirectly fighting alongside the United States in the campaign against the Islamic State. Its client Hizballah remains the dominant force in Lebanese politics. Iranian support is essential to the preservation of the Assad regime in Damascus, even as other rulers challenged by the Arab Spring have fallen. Although Tehran's relationship with the Huthi movement in Yemen is not as strong or as direct as that with Hizballah or the Iraqi militias, the success of the Huthis further contributes to the regional sense that Iran is "on the march." Efforts by other regional powers to challenge Iranian gains have largely failed, whether Turkish and Saudi support for the Syrian opposition (although different elements of it), Saudi financing of the March 14 coalition in Lebanon and military aid to the Lebanese government (now cut off), or half-hearted Saudi efforts to challenge Iran's influence in Iraq. The Saudi-Emirati military campaign in Yemen against the Huthis succeeded in pushing them out of the southern part of the country but not (as of March 2017) out of San'a, the capital. Iran certainly has problems. Its Syrian ally is an increasing burden and will be for some time. Lower oil prices hurt Iran more than the Saudis because Tehran does not have the financial cushion that Riyadh built during recent years of high oil prices. However, it is difficult to argue with the fact that Iran is the regional state that gained the most from changes that commenced with the 2003 US invasion of Iraq.

By pure balance-of-power logic, the region should have witnessed a Turkish-Saudi-Israeli-Egyptian alignment aimed at checking and rolling back Iranian power. All four states have reason to be concerned about Iran, and all have taken steps to check Iranian power and interests. Israel and Saudi Arabia both identify Iran as their primary threat. Turkey has been a consistent supporter of the armed opposition to the Assad regime since the outbreak of the Syrian civil war. Three fourths of this hypothetical balancing alignment-a TurkishSaudi-Egyptian understanding-makes perfect sense by the sectarian logic that many believe is driving regional politics because all three are overwhelmingly Sunni-majority states. However, neither the trilateral nor the quadrilateral balancing alignment against Iran has emerged. Instead, at most, Israel and Saudi Arabia have considered open coordination, whereas at various points, Turkey and Egypt have leaned toward Iran.

Haas (2014) provided a framework to understand this example of regional "underbalancing." He argued that it is not simply power that defines the structure of an international system; identity also plays a role in the way that states define friends and foes. States that share common ideas 
about appropriate and legitimate principles of governance tend to group together. In systems characterized by ideological bipolarity, in which the great powers divide between two overarching systems of governance, alliances tend to follow ideological lines and be stable. However, when there are more than two transnational ideological principles present in the system being advanced by great powers, the likelihood of underbalancing increases.

Haas did not adequately appreciate how regimes that share those common ideas-at least rhetorically_also can be perceived as threats to one another's security. The Communist USSR and the People's Republic of China fell out in the 1960s. Egyptian President Gamal Abdul Nasser was as harsh with fellow "progressive" Arab nationalists who did not toe his line in the 1950 os and 1960 s as he was with the "reactionary" Arab monarchs (Kerr 1971). However, Haas's argument can be refined to accommodate these anomalies. Common ideas about appropriate domestic governance will bring states together as long as respect for state independence and sovereignty underlies those ideas. If those common ideas call for hierarchical institutional forms (e.g., integral unity or formal subordination to a movement's leader), they eventually will be perceived as threats by others in the same ideological camp. from an Islamic perspective. It also challenges the American-led regional order that prevailed since the end of the Cold War, thereby directly challenging the foreign policy of many of its neighbors. Saudi Arabia is directly challenged by the Iranian model, at least among its own Shi'i minority. It supports fellow monarchs and discourages democratic reform both at home and, to some extent (i.e., in its support for the July 2013 coup of General Abd al-Fattah al-Sisi in Egypt), abroad. Under the rule of Recep Tayyib Erdogan (i.e., as prime minister 2003-2014 and since then as president) and his Justice and Development Party (AKP), Turkey has supported a version of Islamist democratic reform in the Arab world, particularly by backing Muslim Brotherhood movements. Although the Islamic State can hardly be called a regional power, it is propounding a transnational salafi ideological model that shares elements of Saudi Arabia's conservative official version of Islam, Iran's revolutionary rejection of the current regional system, and AKP Turkey's Sunni Islamist populism; however, it is a direct threat to all three states. Meanwhile, the Israel of Prime Minister Benjamin Netanyahu continues to hold on to the West Bank and block Palestinian statehood, making it anathema to public opinion throughout the Muslim world.

Haas's model of ideological multipolarity is a good fit for the current Middle East. The Saudis seem uncertain as

\section{The Middle East is currently in a situation of both power and ideological multipolarity.}

Haas (2014, 729) argued that in ideological multipolarity, state leaders will eschew alliances that seem logical from a power perspective because they dislike and fear the ideological stance of a potential ally: "Thus, all other things being equal, a shift from ideological bipolarity to multipolarity will make it more difficult for at least some states to form alliances because there are likely to be fewer ideologically acceptable allies in the system. The greater the impediments to alliance formation, the less efficient the balancing process will be against potential threats." His paradigmatic example was the refusal of conservative politicians in Great Britain and France to consider an alliance with the Soviet Union against Nazi Germany in the 1930s. He added another impediment to effective balancing in ideological multipolarity, already recognized in more Realist accounts of alliance behavior (Christensen and Snyder 1990): that is, the greater incentives for buck passing. Why pay the price for balancing a threat if a third party will do it for free? Why cooperate with an ideological rival in balancing against a third party when cooperating with the rival could have negative repercussions at both home and abroad? In ideologically multipolar situations, therefore, the likelihood of underbalancing is considerable.

The Middle East is currently in a situation of both power and ideological multipolarity. Iran advances a transnational Islamist model that it claims should apply throughout the region, although its strongest appeal is to fellow Shi'a. (For a discussion of the ideological connections that bind Iran and the Assad regime in Syria, see Stein 2017.) The Iranian model rejects monarchy, viewing it as illegitimate to what is their greater threat, Iran or the Islamic State. The seemingly natural Turkish-Saudi balancing alliance against Iran (i.e., both Sunni states want Iranian influence in Syria and Iraq reduced) is impeded by Saudi fears that the Turkish model of populist, democratic Islamism will aid the Muslim Brotherhood in the Arab world. Egypt and Turkey cannot cooperate because of Erdogan's support for the Muslim Brotherhood and al-Sisi's overthrow of the previous Brotherhood president (Trofimov 2016). Egypt broke with Saudi Arabia on Syrian policy despite its massive economic dependence on Riyadh, in part because President al-Sisi shared Assad's view of the war as a necessary campaign against Islamist rebellion. Whereas the Saudis clearly want to roll back Iranian influence in the Arab world, they also have declared the Muslim Brotherhood a terrorist organization (Kirkpatrick 2014). Turkey partnered with Qatar-another regional player that had bet on the Muslim Brotherhood-to encourage Islamist opposition to the Assad regime. However, Turkey now seems to be torn between the goal of Assad's removal, the fear that IS has become the more salient threat to Turkish security, the reality of a renewed Kurdish insurgency in Turkey, and the fallout of the failed coup attempt of July 2016. For ideological and domestic political reasons, Ankara-which historically had decent relations with Israel-chose to distance itself from Jerusalem for most of this period. The desire of some of Israel's US friends to foster a Saudi-Israeli connection against both Iran and IS has not been fully realized, despite signals of covert cooperation in some areas. For domestic and 
regional reputational reasons, Riyadh cannot contemplate an open relationship with the Netanyahu government.

To a great extent, the underbalancing that Haas predicted in ideological multipolarity is driven by fears related to regime security. Leaders are concerned about the domestic effects of transnational ideological messages and therefore are leery of partnering with regional allies whose principles of legitimate domestic governance are in conflict with their own. In this way, using Haas's framework of ideological multipolarity to explain underbalancing in the Middle East is consistent with past work on regional alignments that argued for the primacy of regime-security considerations and the importance of transnational ideological factors in driving alliance decisions (Gause 2003/4; Rubin 2014; Ryan 2009; Stein 2017; see also Lawson 2006 for an interesting counterargument). looks to Sunni powers more than to Iran for support (although Iran has been supportive of Hamas in a common anti-Israeli front). Lebanese and Yemeni Sunnis look to Saudi Arabia for help. However, sectarianism's importance comes from the weakening or breakdown of state authority in many places where, for various reasons, sectarianism has been a salient part of political identity (Salloukh 2017). Lebanese, Syrian, Iraqi, and Yemeni politics all have important sectarian elements. As the state has seen its grip loosen (or completely collapse) in these places, sectarian identities have become more prominent in local struggles for power. Sectarian groups naturally look to their co-sectarians in the region for support-that is, Shi'a to Iran and Sunnis to Saudi Arabia and Turkey. These local groups invite the outsiders into their own domestic conflicts.

\section{As the state has seen its grip loosen (or completely collapse) in these places, sectarian identities have emerged in local struggles for power.}

Defined narrowly as balancing behavior against threats defined by material capabilities, balance-of-power logic cannot provide as comprehensive an explanation for underbalancing in the contemporary Middle East. It certainly can explain why the Saudis, the Egyptians, and even the Turks are concerned about increased Iranian influence in the Arab world. However, it cannot-almost by definition-explain underbalancing. The "natural" power-based and commonenemy alliances against Iran that this pared-down version of the theory would predict-that is, Saudi-Israeli, SaudiTurkish, Turkish-Israeli, and Egyptian-Turkish-have not emerged.

Sectarianism, the most popular framework for understanding the current dynamics of regional politics, also is unsatisfactory in explaining underbalancing. A sectarian perspective assumes that the Sunnis would flock together, but this has not happened. No alliance of Sunni regional powers that would bring together Saudi Arabia and Turkey along with Egypt, Jordan, and the Gulf states has appeared. Rather, alignment patterns among the Sunni states are driven more by ideological compatibility and regime similarity. Saudi Arabia is closely aligned with other monarchs and with the anti-Muslim Brotherhood regime of President al-Sisi in Egypt. Turkey was more closely aligned with Qatar under Amir Hamad bin Khalifa Al Thani (who ruled from 1995 to 2013), when Doha was more actively backing Muslim Brotherhood causes; with Egypt under the brief Brotherhood government of President Muhammad Morsi (2012-2013); and with the Hamas administration in Gaza.

This is not to argue that sectarianism is unimportant in the current alignment picture in the region. There is an elective affinity between Iran and Shi'i groups: Hizballah, various Iraqi Shi'i militias, and the Huthis (although they belong to a different variant of Shi'ism than the Iranians, the Huthi movement adopted the ideology and rhetoric of the Islamic Republic). Historically, the Muslim Brotherhood
The sectarian template emerges from below; it is not imposed from above.

\section{CONCLUSION}

Haas $(2014,732)$ conceded that alliances across ideological lines in ideological multipolarity are possible; they simply are more difficult to achieve than Realist interpretations of balance-of-power theory would predict. If powers in different ideological poles independently come to view a third power as both their most salient power threat and their most salient ideological threat, then a balancing alliance can form against that third power across ideological lines. Thus, the Western democracies and the Soviet Union eventually allied against Nazi Germany-although it took a while for them to finally do so.

Haas (2014: 720, 741-9) followed Katzenstein in asserting that "identities cannot be stipulated deductively. They must be investigated empirically in concrete historical circumstances." British and French conservatives were more concerned about the ideological threat of the Soviet Union in the 1930s than British and French socialists. Were the Left in power in London or in Paris for more than a few months at that time, there would have been fewer obstacles to the alliance that was eventually formed between the democracies and the Communists. Leaders' perceptions of threat comprise the key element, and those perceptions can change over time, or new leaders with different perceptions can come to power. This has certainly been true in the Middle East.

King Salman of Saudi Arabia, who came to power in 2015, is more willing to set aside fears of the Muslim Brotherhood than his predecessor. He reached out to Ankara to cooperate more closely on Syrian issues and activated ties with the Islah Party in Yemen, in which Yemen's Muslim Brotherhood branch plays a major role. Islah then supported the SaudiEmirati military campaign in Yemen. President Erdogan, aware of Turkey's regional isolation after the fall of Muslim 
Brotherhood rule in Egypt and the Syrian opposition's inability to dislodge Assad from power, was open to the Saudi initiative in 2015. Elements of the Syrian opposition supported by Saudi Arabia and Turkey began working more closely together after that, although their brief battlefield successes in early 2015 were quickly checked by the increased Russian role in Syria. In June 2016, Erdogan reestablished diplomatic relations with Israel as well. However, there is no indication that the deep rift between Ankara and Cairo is healing. Moreover, the regional fallout of the failed July 2016 coup attempt in Turkey might alter Erdogan's views of the most salient threat to his own regime's security. The general belief in Turkey that the United States was somehow supportive of the coup, and Erdogan's immediate overtures after the coup toward Russia and Iran, could presage another shift in Turkey's regional alignment, away from balancing Iranian power (Arango and Yeginsu 2016). It remains true that no Muslim Middle Eastern state is willing to ally openly with Israel in an anti-Iranian pact.

With all the fluctuations that characterizes Middle East international politics, it remains an interesting puzzle for students of regional alliances why it has taken so long for other Middle Eastern states to align against Iran-if, in fact, that is what they are doing. This instance of underbalancing is best explained not by sectarianism or capabilities-based understandings of power but rather by concerns about ideological differences among the leaders of these potential partners and the effect those differences could have on domestic-regime security. $\mathrm{n}$

\section{REFEREN CES}

Arango, Tim and Ceylan Yeginsu. 2016. "Turks Can Agree on One Thing: U.S. Was Behind Failed Coup." New York Times, August 3. Available at www. nytimes.com/2016/o8/o3/world/europe/turkey-coup-erdogan-fethullahgulen-united-states.html.

Christensen, Thomas J. and Jack Snyder. 1990. "Chain Gangs and Passed Bucks: Prediction Alliance Patterns in Multipolarity.” International Organization 44 (2): 137-68.
Gause, F. Gregory III. 2003/4. "Balancing What? Threat Perception and Alliance Choice in the Gulf." Security Studies 13 (2): 273-305.

_. 2014. "Beyond Sectarianism: The New Middle East Cold War." Doha, Qatar: Brookings Doha Center Analysis Paper No. 11. Available at www.brookings.edu/research/papers/2014/o7/22-beyond-sectarianismcold-war-gause.

Haas, Mark L. 2014. "Ideological Polarity and Balancing in Great Power Politics." Security Studies 23 (4): 715-53.

Kerr, Malcolm H. 1971. The Arab Cold War. London: Oxford University Press.

Kirkpatrick, David D. 2014. "Saudis Put Terrorist Label on Muslim Brotherhood." New York Times, March 8. Available at www.nytimes. com/2014/03/o8/world/middleeast/saudis-put-terrorist-label-onmuslim-brotherhood.html.

Lawson, Fred H. 2006. Constructing International Relations in the Arab World. Stanford, CA: Stanford University Press.

Lynch, Marc. 2016. The New Arab Wars: Uprisings and Anarchy in the Middle East. New York: Public Affairs.

Rubin, Lawrence P. 2014. Islam in the Balance: Ideational Threats in Arab Politics. Redwood City, CA: Stanford University Press.

Ryan, Curtis R. 2009. Inter-Arab Alliances: Regime Security and Jordanian Foreign Policy. Gainesville: University Press of Florida.

- 2012. "The New Arab Cold War and the Struggle for Syria." Middle East Report 42 (262). Available at www.merip.org/mer/mer262/new-arab-coldwar-struggle-syria.

Salloukh, Bassel F. 2013. "The Arab Uprisings and the Geopolitics of the Middle East.” The International Spectator: Italian Journal of International Affairs 48 (2): 32-46.

- 2017. "Overlapping Contests and Middle East International Relations: The Return of the Weak Arab State." PS: Political Science \& Politics 50 (3): this issue.

Schweller, Randall L. 2004. "Unanswered Threats: A Neoclassical Realist Theory of Underbalancing." International Security 29 (2): 159-201.

. 2006. Unanswered Threats: Political Constraints on the Balance of Power. Princeton, NJ: Princeton University Press.

Stein, Ewan. 2017. "Ideological Codependency and Regional Order: Iran, Syria, and the Axis of Refusal." PS: Political Science \& Politics 5o (3): this issue.

Trofimov, Yaroslav. 2016. "Feuding Friends Frustrate Saudi Efforts to Counter Iran." Wall Street Journal, June 3o. Available at www.wsj.com/articles/feudingfriends-frustrate-saudi-efforts-to-counter-iran-146727900o.

Valbjørn, Morten. 2017. "Strategies for Reviving the International Relations/ Middle East Nexus after the Arab Uprisings.” PS: Political Science $\mathcal{E}$ Politics 50 (3): this issue.

Walt, Stephen M. 1987. The Origins of Alliances. Ithaca, NY: Cornell University Press. 